\title{
Agronomic and socio-economic analysis of water management techniques for dry season cultivation of common bean in Malawi
}

\author{
Davie M. Kadyampakeni • Henry R. Mloza-Banda • \\ Darwin D. Singa $\cdot$ Julius H. Mangisoni $\cdot$ \\ Anne Ferguson · Sieglinde Snapp
}

Received: 28 November 2011/ Accepted: 12 March 2012/Published online: 28 March 2012

(C) Springer-Verlag 2012

\begin{abstract}
A study was carried out in Malawi to compare agronomic and socio-economic aspects of different water management practices for two advanced bean lines. Four irrigation technologies and one control were studied in Chingale Area Development Program in Zomba District in southern Malawi. The technologies encompassed motorized pumps (MP), treadle pumps (TP), water cans, gravityfed surface irrigation (GR) and a non-irrigated practice that used residual moisture. The study found that technologies that used $<2$ labour hours $\mathrm{m}^{-3}$ were appropriate for such
\end{abstract}

Communicated by Amir Kassam.

\section{M. Kadyampakeni}

Department of Agricultural Research Services, Kasinthula Research Station, Ministry of Agriculture and Food Security, Irrigation Agronomy Section, P.O. Box 28, Chikwawa, Malawi

D. M. Kadyampakeni · H. R. Mloza-Banda .

D. D. Singa $\cdot$ J. H. Mangisoni

Bunda College of Agriculture, University of Malawi,

P.O. Box 219, Lilongwe, Malawi

e-mail: mlozab@yahoo.co.uk

D. D. Singa

e-mail: dodoma@bunda.unima.mw

J. H. Mangisoni

e-mail: jmangisoni@yahoo.co.uk

D. M. Kadyampakeni ( $\varangle)$

Soil and Water Science Department, University of Florida,

2685 SR 29 N, Immokalee, FL 34142, USA

e-mail: dakadyampakeni@yahoo.com

A. Ferguson - S. Snapp

Michigan State University, East Lansing, MI 48824-1325, USA

e-mail: fergus12@msu.edu

S. Snapp

e-mail: snapp@msu.edu small-scale irrigation systems. The aggregated bean production labour cost and labourday thresholds were $\$ 893 \mathrm{ha}^{-1}$ and 2,978 $\mathrm{LD} \mathrm{ha}^{-1}$, respectively. An irrigation supply in the range of 7,000-10,000 $\mathrm{m}^{3} \mathrm{ha}^{-1}$ for the TP, MP and GR would be adequate. Assuming 20 irrigations season $^{-1}, 400-600 \mathrm{~m}^{3}$ irrigation $^{-1}$ would be adequate, supplying 40-60 mm every 5-7 days. The study found that poor small-scale farmers in Malawi, particularly those using MPs, need fuel subsidies in order to offset operational costs. Basing on the findings in the study, we recommend further research on several bean lines in different agro-ecologies of Malawi using technologies that showed high yields, low labour efficiency and high water use productivity.

Keywords Dry season - Irrigation management .

Phaseolus vulgaris · Socio-economic · Water use efficiency

\section{Introduction}

As land pressure and climate change intensify, Malawi is turning increasingly to irrigated agriculture as a means to increase agricultural production. Irrigated agriculture is regarded as a means to boost incomes and food security and is considered a way to reduce poverty by government and donors (Mulwafu and Nkhoma 2002; Mulwafu et al. 2003; Ferguson and Mulwafu 2004; Kambewa 2004; Nkhoma and Mulwafu 2004; Peters 2004; Mangisoni 2008; Chidanti-Malunga and Weatherhead 2009). There is a big potential for irrigation in Malawi, which can impact positively on food security, and every effort needs to be taken to harness this potential. It is reported that potential land for irrigation in Malawi is 400,000 ha, while only 62,000 ha is currently under irrigation of which only 
14,000 ha is owned by smallholder farmers (FAO 1996; Malawi Government 2000; Maweru 2004). In Malawi, a number of modern and simple irrigation technologies are used in the dry season to promote crop production among small-scale farmers (Wiyo et al. 2002; Fandika et al. 2007; Kadyampakeni et al. 2008; Mangisoni 2008; ChidantiMalunga and Weatherhead 2009; Fandika et al. 2012).

Although there is increasing recognition of irrigated agriculture to support the food security objective of the Malawi government, no study has evaluated the agronomic and socio-economic aspects of the different irrigation systems currently in use among smallholder farmers in the country. It is important to assess the benefits of the different irrigation systems, so that only cost-effective and labour-efficient technologies that match the socio-economic realities of the smallholder farmers are promoted. When water is scarce, as is the case during the dry season in Malawi, allocation of irrigation water to competing crops or plots is a prime consideration (Chidanti-Malunga and Weatherhead 2009; de Fraiture and Wichelns 2010; de Fraiture et al. 2010). For greater efficiency, it is important to use the most effective irrigation technology or system for applying water. The study was conducted to compare agronomic and socio-economic aspects of water management practices for common bean cultivation in the dry season in Malawi. The study focused on irrigated and residual moisture water management techniques. Smallholder farmers managed all the treatments with the professional backup of World Vision Malawi personnel and scientists from Bunda College of Agriculture. Irrigation technologies used in the study included motorized and treadle pumps (TP), water cans (WC) and gravity-fed surface irrigation (GR).

\section{Methodology}

The study was conducted in Chingale Area Development Program of Zomba District in Southern Malawi. Chingale Area Development Program lies at a latitude of approximately $15^{\circ} 32^{\prime} \mathrm{S}$ and longitude $35^{\circ} 11^{\prime} \mathrm{E}$. The site was chosen because it is where dambo utilization for crops such as beans, maize, rice and vegetables is thriving through efforts of the World Vision (Malawi) Food Security Program. In Malawi, a dambo is described as "any permanently or seasonally wet land in valleys, depressions, or floodplains with open herbaceous vegetation, mainly grasses and sedges, and an absence of trees" (FAO 1996). World Vision Malawi is promoting soil and water management techniques for crop production in the area.

Irrigation and water management data collected included number of WC used, irrigation time, pumping time, suction and delivery heads for pumps, and irrigation depths. Also, actual volume of water applied to the bean crop was estimated and recorded and later analysed using SPSS 9.0 and Excel spreadsheets. Volume of water used from source per unit area was determined for diesel and $\mathrm{TP}$, the bucket (water can) and gravity diversion using suggested methods of Hansen et al. (1980). For the pump:

$V_{\mathrm{wa}}=I_{\mathrm{d}} \times Q$

where $V_{\text {wa }}$ is volume of water applied $\left(\mathrm{m}^{3}\right), I_{\mathrm{d}}$ is irrigation duration (s), and $Q$ is discharge $\left(\mathrm{m}^{3} / \mathrm{s}\right)$. For the water can that had a standard volume of $10 \mathrm{~L}$,

$V_{\mathrm{wa}}=N_{\mathrm{ow}} \times V_{\mathrm{pw}}$

where $N_{\text {ow }}$ is number of WC of water applied and $V_{\mathrm{pw}}$ is volume per water can $\left(\mathrm{m}^{3}\right)$. For furrow irrigation,

$V_{\text {wa }}=Q \times T$

where $Q$ is discharge or flow rate $\left(\mathrm{m}^{3} / \mathrm{s}\right)$ and $T$ is time of flow (s). In this case, water was introduced into the field, and an observer waited till water reached the farthest end of the field. The gross amount of irrigation water applied per plot was calculated by dividing the volume of water applied $\left(\mathrm{m}^{3}\right)$ by the area $\left(\mathrm{m}^{2}\right)$. Due to difficulty in measuring net water application on-farm, the gross amount of water applied was assumed to be available to the bean plant while negating effects of deep percolation and surface run-off.

The TP were used where there are rivers or wells with total heads $\leq 2.5 \mathrm{~m}$. Motorized pumps (MP) were used at total pumping heads $\geq 6.6 \mathrm{~m}$ in large rivers, at low labour supply but with very high discharge rate. Suction heads, delivery lifts and total pumping heads across the treatments that used pumps ranged from 1.1 to $7.5 \mathrm{~m}$. Conveyance distances were variable across the irrigated treatments and ranged from 24 to $200 \mathrm{~m}$. Farmers using the water can had the highest irrigation frequency. As expected, farmers using MP realized the lowest irrigation frequency.

The crop water consumptive use $\left(\mathrm{ET}_{\mathrm{c}}\right)$ was computed from climatic data using the standard FAO PenmanMonteith method for $\mathrm{ET}_{\mathrm{o}}$ calculation and the FAO CropWat program for estimating reference crop evapotranspiration on daily basis (Allen et al. 1998). The climatic data used were sourced from Chileka International Airport, which lies at $767 \mathrm{~m}$ above sea level, within the same agro-ecological zone as Chingale. Chingale lies at $680 \mathrm{~m}$ above sea level. The reference evapotranspiration $\left(\mathrm{ET}_{\mathrm{o}}\right)$ was then multiplied by a crop coefficient at a particular growth stage to determine crop consumptive use at that particular stage of bean growth where $\mathrm{ET}_{\mathrm{c}}$ is given as:

$\mathrm{ET}_{\mathrm{c}}=K_{\mathrm{c}} \times \mathrm{ET}_{\mathrm{o}}$

where $\mathrm{ET}_{\mathrm{c}}$ is crop evapotranspiration in $\mathrm{mm} \mathrm{day}^{-1} ; K_{\mathrm{c}}$ is crop coefficient dependent on crop growth stage; and $\mathrm{ET}_{\mathrm{o}}$ is reference crop evapotranspiration $\left(\mathrm{mm} \mathrm{day}^{-1}\right)$. 
A total of 27 farmers and a maximum of three farms (area of $10 \mathrm{~m} \times 10 \mathrm{~m}=100 \mathrm{~m}^{2}$ ) for each treatment were used in the ADP's wetlands (locally called dambos) for the experiment, and each farmer served as a replicate. Soil samples were collected in the study area in the top 0-30 cm. The average soil physico-chemical characteristics of area are the following: $\mathrm{pH}$ (5.2), organic carbon $(1.12 \%)$, organic matter $(1.89 \%)$ and bulk density $\left(1.52 \mathrm{~g} \mathrm{~cm}^{-3}\right)$ with predominantly sandy clay loam textural class. Two advanced bean lines (BCMV-B2 and IZ 309-1) were grown.

All treatments were planted between 1 and 5 May. Measurements were taken from the net plot $\left(36 \mathrm{~m}^{2}\right.$ located in the centre of each farm) by leaving out $2 \mathrm{~m}$ on all four sides of farm as buffers against livestock. A total of 100 and 66 bean seeds were planted singly per planting station on each row giving plant populations of 220,000 plants $\mathrm{ha}^{-1}$ and 92,400 plants $\mathrm{ha}^{-1}$ for the dwarf and climber beans, respectively. The respective intra-row spacings for dwarf and climber lines were 10 and $15 \mathrm{~cm}$, while the inter-row spacings were 45 and $75 \mathrm{~cm}$. The climbing beans were supported by 2-m stakes. Because the trial was on two bean types, two plots separated by a 1-m boundary were assigned to each farmer to ensure statistical replication of the treatments. All treatments except MP were harvested between 16 and 20 August, while MP was harvested between 6 and 8 September, due to some problems in

Table 1 Conversion rates employed in estimating contribution of family labour of household members by availability of household member, gender and age category

\begin{tabular}{|c|c|c|c|c|}
\hline $\begin{array}{l}\text { Availability of } \\
\text { member }\end{array}$ & Gender & $\begin{array}{l}<15 \text { years } \\
\text { (man- } \\
\text { equivalents) }\end{array}$ & $\begin{array}{l}\text { 15-59 years } \\
\text { (man- } \\
\text { equivalents) }\end{array}$ & $\begin{array}{l}>60 \text { years } \\
\text { (man- } \\
\text { equivalents) }\end{array}$ \\
\hline \multirow{2}{*}{$\begin{array}{l}\text { Permanent } \\
\text { resident }\end{array}$} & M & 0.2 & 1.0 & 0.6 \\
\hline & $\mathrm{F}$ & 0.2 & 0.8 & 0.4 \\
\hline \multirow{2}{*}{$\begin{array}{l}\text { Permanent } \\
\text { resident in } \\
\text { local } \\
\text { employment }\end{array}$} & M & - & 0.2 & - \\
\hline & $\mathrm{F}$ & - & 0.2 & - \\
\hline \multirow{2}{*}{$\begin{array}{l}\text { Permanent } \\
\text { resident in } \\
\text { full-time } \\
\text { education }\end{array}$} & M & 0.1 & 0.5 & - \\
\hline & $\mathrm{F}$ & 0.1 & 0.4 & - \\
\hline $\begin{array}{l}\text { Polygamist } \\
\text { spending } \\
\text { part of time } \\
\text { in other } \\
\text { household }\end{array}$ & M & - & 0.5 & 0.5 \\
\hline \multirow{2}{*}{$\begin{array}{l}\text { Resident hired } \\
\text { labour }\end{array}$} & M & 0.5 & 1.0 & 0.7 \\
\hline & $\mathrm{F}$ & 0.5 & 1.0 & 0.7 \\
\hline
\end{tabular}

After: Mangisoni (1999)

- nil; - not applicable

$M$ Male, $F$ Female accessing the field site at the time of harvest resulting in a total of 115 days for the former four treatments and 135 days for the MP. Data collection included 100 seed weight (g), 100 seed dry weight (at $10 \%$ moisture content) in grams, total yield ( $\mathrm{g}$ ) from all seeds collected from the net plot. This set of data helped to estimate yield $(Y)$ in $\mathrm{kg} \mathrm{ha}^{-1}$ using a standard formula:

$$
\begin{aligned}
Y= & {\left[\mathrm{DM}_{1}(\mathrm{~g}) / \mathrm{DM}_{2}(\mathrm{~g})\right] \times[\operatorname{Net} \text { plot yield }(\mathrm{g}) / 1,000(\mathrm{~g})] } \\
& \times\left[10,000\left(\mathrm{~m}^{2}\right) / \operatorname{Plot} \operatorname{size}\left(\mathrm{m}^{2}\right)\right]
\end{aligned}
$$

where $\mathrm{DM}_{1}$ is dry matter after harvest and $\mathrm{DM}_{2}$ is dry matter at $10 \%$ moisture content.

General recommended crop management practices including weeding, fertilizer application and pest and disease control were done around the same time in all the treatments to factor out agronomic management effects. Planting was done using a seed rate of $90 \mathrm{~kg} \mathrm{ha}^{-1}$, and 23:21:0 + 4S fertilizer was applied at the rate of $200 \mathrm{~kg} \mathrm{ha}^{-1}$. The smallholder farmers were responsible for irrigating the bean crop using the provided technologies but following closely the treatment designs. The amount of water applied to the bean crop during the season was recorded for each treatment in order to facilitate the estimation of the amount of water the farmers applied to the bean crop in each treatment. Researchers in conjunction with field officers and farmers from World Vision Malawi a non-governmental organization (NGOs) in Zomba recorded the volume of gross water applied per irrigation. Socio-economic aspects of dry season bean production were evaluated through determination of labour (Table 1). Available labour was estimated by aggregating and categorizing members in each household according to gender, age category and availability using methods outlined by Mangisoni (1999). The social characteristics of the farmers and labour like age and sex were determined during a parallel baseline survey conducted during the study. Labour costs were calculated based on the measured hours per irrigation for each technology from Table 2 that allowed the estimations of $\mathrm{LH} \mathrm{ha}^{-1}$ season $^{-1}$ and $\mathrm{LD} \mathrm{ha}{ }^{-1}$. The maintenance costs for each irrigation technology were estimated from the work done in repairing or replacing some parts of the technology in question by using the cost of spare parts or any charges related to the repairs for each plot and subsequently converted to per ha basis.

\section{Results and discussion}

Agronomic evaluation of water management practices

Yield and water use performance parameters for the five water management practices are presented in Table 2 . The 
yields realized in the study compare well with those found by Tefera (2006) and Makwiza (2008). Average yields of BCMV-B2 observed in the study were $36 \%$ higher than the average yields of the same line $\left(921 \mathrm{~kg} \mathrm{ha}^{-1}\right)$ reported by Mwale et al. (2008) in five agro-ecologies of Malawi under rainfed conditions. Edje et al. (1981) suggested that irrigated bean production might be better than production under rainfed conditions because the bean crop averts microbial diseases associated with the rainy season. The yields of the climber line also compare very well with wellmanaged climber bean under rainfed conditions (Mwale et al. 2009). Grain yields differed significantly $(p<0.001)$ across irrigation technologies. GR produced the highest mean yield (2,278 and $\left.1,713 \mathrm{~kg} \mathrm{ha}^{-1}\right)$, while farmers using RM realized lowest yield (522 and $350 \mathrm{~kg} \mathrm{ha}^{-1}$ ) for the dwarf and climber bean, respectively. Overall, the dwarf bean yield $\left(1,199 \pm 662 \mathrm{~kg} \mathrm{ha}^{-1}\right)$ was higher than that of climber bean $\left(784 \pm 542 \mathrm{~kg} \mathrm{ha}^{-1}\right)$. Fairly low yields were obtained with MP and TP treatments compared with GR due to grasshopper attack on some plots where the former two treatments were installed, resulting in significantly lower yields than the latter. However, most of the results are ascribed mainly to differences in water management because all the plots were subjected to similar agronomic practices (weeding, fertilization, pest control). Also, the farmers and extension officers in the area were trained on water management, pump maintenance, data collection and associated practices for standardization of data collection protocols and facilitation of technology transfer at the end of the project. It was interesting in the study that most of the farmers involved had indigenous knowledge of some of the technologies that were being introduced and/or promoted in the area.

Water use efficiency (WUE) and water use productivity (WUP) were calculated according to procedures described in Molden et al. (2003). WUE, an indication of irrigation efficiency of each irrigation technology, was calculated as a dimensionless fraction of the volume of water effectively used $\left(E_{c}, \mathrm{~m}^{3}\right)$ over the volume of water supplied $\left(\mathrm{m}^{3}\right)$. Accordingly, WUP was defined as grain yield $(\mathrm{kg})$ divided by the volume of water consumed by the crop $\left(\mathrm{m}^{3}\right)$ (Sinclair et al. 1984; Howell 2001; Molden et al. 2003). Our WUE values were somewhat lower than those obtained by Fernández et al. (2007) and Fandika et al. (2012), who conducted their studies under drip-irrigated and/or greenhouse conditions. The WUEs in our study ranged from $0.15 \mathrm{~m}^{3} \mathrm{~m}^{-3}$ using GR to $1.08 \mathrm{~m}^{3} \mathrm{~m}^{-3}$ using WC. The WUE for WC of $1.08 \mathrm{~m}^{3} \mathrm{~m}^{-3}$ suggests that water stress might have occurred with the system as a result of underirrigation. Farmers applied about $3,290 \mathrm{~m}^{3}$, much lower than $3,564 \mathrm{~m}^{3}$ that would be required for crop consumptive use for the whole season. The water use using RM, as expected, was low $\left(1,865 \mathrm{~m}^{3}\right)$ as estimated with CROPWAT 8.0. In all irrigation scenarios, the dwarf bean BCMV-B2 produced WUPs over two times higher than those obtained in the climber line IZ301-1 averaging $0.35 \pm 0.17$ and $0.23 \pm 0.14 \mathrm{~kg} \mathrm{~m}^{-3}$, respectively, suggesting that the dwarf line was more efficient in converting soil water into grain yield. WUP was highest with GR and lowest with RM, as expected, for both the climber and dwarf bean. The TP irrigation technology ranked second to GR with regard to WUP. Gravity-fed surface irrigation was more efficient in converting soil water into grain yield, while residual moisture was the least efficient. When all irrigation treatments were compared with the RM, irrigation technologies increased WUPs by $34-395 \%$ in both bean lines. Thus, irrigation appears to substantially increase yields compared with use of residual moisture alone. The results on low WUEs point to the low irrigation efficiencies in small-scale irrigated farming systems as was observed in the study. For example, the analysis clearly showed that despite having the highest yields and corresponding revenue, GR was the least efficient technology with regard to water use. Assuming that water was a costed

Table 2 Performance of the water management practices: water supply, water use and bean yield

\begin{tabular}{|c|c|c|c|c|c|c|c|c|}
\hline IT & IF & IS ha ${ }^{-1}$ & $\mathrm{ET}_{\mathrm{c}} \mathrm{ha}^{-1}$ & Y1 & Y2 & WUE & WUP1 & WUP2 \\
\hline MP & 21 & 13,680 & 4,244 & $1,041.7$ & 745.3 & 0.31 & 0.25 & 0.18 \\
\hline $\mathrm{TP}$ & 16 & 7,740 & 3,564 & $1,273.3$ & 650.5 & 0.46 & 0.36 & 0.18 \\
\hline WC & 132 & 3,290 & 3,564 & 880.0 & 463.0 & 1.08 & 0.25 & 0.13 \\
\hline GR & 20 & 23,190 & 3,564 & $2,278.0$ & $1,713.0$ & 0.15 & 0.64 & 0.48 \\
\hline $\mathrm{RM}$ & NA & NA & 1,865 & 522.0 & 350.0 & NA & 0.28 & 0.19 \\
\hline Sign. & & & NS & $* * *$ & $* * *$ & & $* * *$ & $* * *$ \\
\hline $\mathrm{CV}(\%)$ & & & 15.2 & 55.2 & 69.1 & & 60.3 & 74.2 \\
\hline
\end{tabular}

$I T$ irrigation technology, $M P$ motorized pump, $T P$ treadle pump, $W C$ water can, $G R$ gravity irrigation, $R M$ non-irrigated treatment using residual moisture, Sign. statistical significance: $N S$ not significant at $p=0.05, * * *$ refers to significance at $p<0.001, I F$ irrigation frequency, $I S$

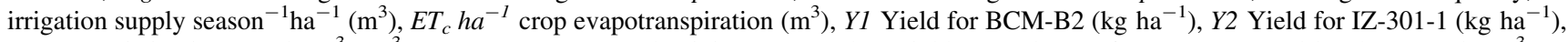
WUE ET /irrigation supply $\left(\mathrm{m}^{3} \mathrm{~m}^{-3}\right), W U P$ water use productivity expressed as yield per volume of water consumed by the crop $\left(\mathrm{kg} \mathrm{m}^{3}\right)$ as defined in Molden et al. (2003), WUP1 WUP BCMV-B2 $\left(\mathrm{kg} \mathrm{m}^{-3}\right)$, WUP2 WUP IZ-301-1 $\left(\mathrm{kg} \mathrm{m}^{-3}\right)$, NA not applicable 
resource in the study area, such farmers would have limitations on the amount of water irrigated. The farmers using GR applied approximately 10 times the amount of water actually consumed by the crop, suggesting that most of the water applied might have been lost to surface run-off, evaporation and downward drainage. Similarly, farmers using MP and TP applied about 3-4 times the amount of water actually used by the crop, demonstrating that water losses as was the case of GR might have resulted. Our study showed that TP, MP and GR applied water for about 16-21 times during the season with irrigation supply of $7,740-23,190 \mathrm{~m}^{3}$. All the three treatments met irrigation and crop water requirements, while WC resulted in underirrigation despite receiving 132 irrigations. Thus, an irrigation supply falling between 7,000 and $10,000 \mathrm{~m}^{3} \mathrm{ha}^{-1}$ per season for the TP, MP and GR would be adequate, taking into account some losses. Assuming 20 irrigations per season, $400-600 \mathrm{~m}^{3}$ per irrigation would be adequate, supplying 40-60 mm every 5-7 days. However, the surface water application for GR should be modified to furrow or corrugation, other than flooding as was the case in the study, to minimize deep percolation and other conveyance losses. The limitation of the study lied in failing to control the amount of water each farmer applied because of differences in water sources and farmer location. We paradoxically thought at the conceptualization of the field work that one way of promoting indigenous knowledge and technology up- and out-scaling in on-farm water management was to let the farmers handle the water application 'their way' as long as adequate moisture was retained in the root zone. Thus, the low WUEs and WUPs are probably due to inadequate and possibly unreliable water deliveries in the crop root zone. Thus, skills on basic periodic soil sampling or field techniques for measuring soil moisture content should be inculcated in our small-scale farmers for use in soil water balance/budgeting to avoid applying excessive water to the crop as was the case with GR. The farmers using MP and TP applied water using PVC pipe tubing into the main canal that delivered the water to the corrugated furrows in the crop rows, such that irrigation losses were due to deep percolation or evaporation or overflowing. The farmers using GR diverted water from small streams uphill and had signed agreements with their counterparts near the water sources to let them divert onehalf of the stream-flow to their fields downstream (most of these agreements were facilitated by local leaders and there were no issues with regard to water distribution and management) through earth canals, then into the main canals and subsequently the crop field. Tindamanyire (2003) and Mwendera (2003) also showed in their studies that low irrigation water application resulted in low yields. The WUPs observed in MP, TP and WC were similar and agreed with observations by Pereira et al. (2002). The soil moisture distribution (Fig. 1) showed that there was adequate soil water to promote vegetative growth and yield. At planting, soil moisture ranged from $15.5 \pm 3.1$ to $26.3 \pm 3.4 \mathrm{~cm}^{3} \mathrm{~cm}^{-3}$, and from $9.8 \pm 1.3$ to $14.2 \pm 1.2 \mathrm{~cm}^{3} \mathrm{~cm}^{-3}$ at harvesting. High soil water contents (ranging from $22.3 \pm 2.2$ to $31.6 \pm 2.2 \mathrm{~cm}^{3} \mathrm{~cm}^{-3}$ ) observed during vegetative and reproductive stages in all treatments suggest that water availability was not a limitation in the study across all technologies during these sampling times. However, as the irrigation frequencies showed in Table 2, farmers irrigated every $4-5$ days using the pumping technologies and thus, might have possibly, resulted in some periods of moisture stress at some critical stages that lowered yields for these treatments, despite meeting the crop water requirement.

Labour requirement and costs of the water management practices

Because of its highest irrigation frequency, use of WC had the highest total labour costs totalling $\$ 1,179.4 \mathrm{ha}^{-1}$ with labour input of 3,931 labourdays ha ${ }^{-1}$ (Table 3). The labour cost for WC was approximately 2, 4 and 7 times that of TP, MP and RM, but slighter higher than GR $(\mathrm{WC} \approx 1.3 \mathrm{GR})$. The high labour costs for the WC and GR are due to very high irrigation frequency (132 irrigation turns using WC, irrigating approximately twice a day) and long times spent controlling water distribution on-farm with GR (according to farmers' experiences among

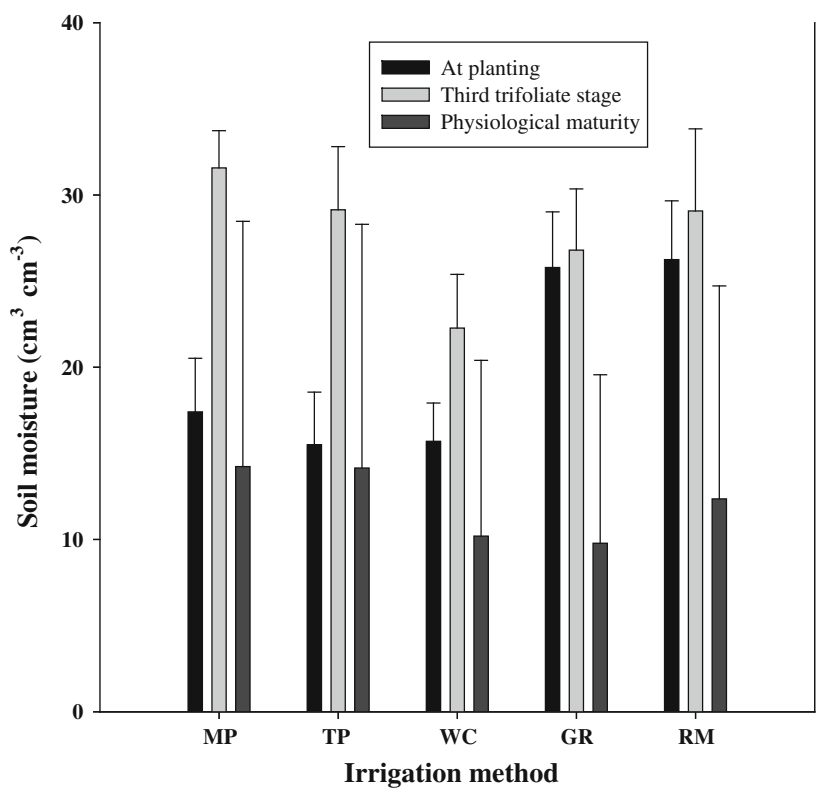

Fig. 1 Volumetric soil moisture measured at $20 \mathrm{~cm}$ depth at planting, third trifoliate and physiological maturity stages. Error bars represent one standard deviation, $M P$ motorized pump, $T P$ treadle pump, $W C$ water can, $G R$ gravity irrigation, $R M$ non-irrigated treatment (using residual moisture) 
themselves). Accordingly, labourdays (LD) $\mathrm{ha}^{-1}$ and labourhours (LH) ha ${ }^{-1}$ followed a pattern similar to that of labour costs. However, LH per irrigation turn decreased in the following pattern GR $>$ TP $>$ MP $>$ WC because from the field experiments, the GR, TP and MP required about 2-4 people at each irrigation compared with $\mathrm{WC}$ where one person could irrigate the plots at each irrigation event. Chisenga (2004) also reported that the WC is labourintensive, time-consuming and requires much effort. Another school of thought ascribes the use of water can to capital constraints to upgrade technology, or terrain may preclude use of some of these technologies. TP treatments had a high labour demand because of water extraction (through pumping), application and priming procedures. This finding agrees with Chimpeni (2004), who reported that TP discourage the participation of vulnerable groups such as women and the sick because they are labourintensive. The aggregated bean production labour cost and labourday (LD) thresholds per ha were found to be $\$ 893 \mathrm{ha}^{-1}$ and 2,978 $\mathrm{LD} \mathrm{ha}^{-1}$. The labour threshold values suggest that use of the water can is not cost-effective with regard to labour use. From our study, it appears that farmers who opted for the water can were those with more available labour. However, to help farmers upgrade to larger irrigated areas, use of the other technologies such as TP, MP and GR would be recommended for high yield, revenue and reasonable cost particularly where land and water resources permit. With an increasing population in countries like Malawi, competing water demands for industrial, domestic and recreational uses will increase, thereby calling for increased efficiency in managing the water resource in agricultural production. Modifications into using more efficient small-scale water application methods as demonstrated in Kenya (Kabutha et al. 2000) and Malawi (Fandika et al. 2007, 2012) would be appropriate for increasing crop yields and reducing the ardour and time farmers spend on water management. The MP irrigation technologies had the lowest labour costs $\left(\$ 300 \mathrm{ha}^{-1}\right)$ compared with other treatments. The low labour demands established in MP are consistent with the findings of Kintomo et al. (1997) in Nigeria, who noted that due to initial clearing operations, construction of drainage channels and seed bed preparations, labour used in dry season crop cultivation varied from 3,000 to $10,000 \mathrm{LH}$ $\mathrm{ha}^{-1}$ for manual lift and MP. The rest of the TP, WC and GR, respectively, had labour use well above 10,000 LH $\mathrm{ha}^{-1}$. This is attributed to differences in water extraction, conveyance and application. Some of the additional labours were used on agronomic practices such as planting, weeding and staking. In addition, moving from a manual lift technology to a motor pump represents significant labour saving for the farmer because he/she can irrigate at higher flow rates and less time and effort. Also, the labour efficiency (LE) derived from the number of hours spent on irrigation per $\mathrm{m}^{3}$ of water applied confirmed that WC $(9.54$ $\left.\mathrm{LH} \mathrm{m}^{3}\right)$ and TP $\left(1.94 \mathrm{LH} \mathrm{m}^{3}\right)$ were indeed labour-intensive. MP and GR had LEs of 0.58 and $1.03 \mathrm{LH} \mathrm{m}^{-3}$, suggesting that LE for an appropriate water management technology should probably fall below $2.00 \mathrm{LH} \mathrm{m}^{-3}$. However, the fuel cost for farmers using the MP technology was

Table 3 Performance of the water management technologies: operational and investment costs, revenue from grain yield, labour and labour costs

\begin{tabular}{|c|c|c|c|c|c|c|c|c|c|c|c|c|c|}
\hline $\begin{array}{l}\text { Irrigation } \\
\text { technology }\end{array}$ & $\begin{array}{l}\mathrm{LH} \mathrm{ha}^{-1} \\
\text { irrigation }^{-1}\end{array}$ & $\begin{array}{l}\mathrm{LH} \mathrm{ha}^{-1} \\
\text { season }^{-1}\end{array}$ & $\begin{array}{l}\mathrm{LH} \\
\mathrm{m}^{-3}\end{array}$ & $\begin{array}{l}\mathrm{LD} \\
\mathrm{ha}^{-1}\end{array}$ & $\begin{array}{l}\mathrm{LE} \\
(\mathrm{LH} \\
\left.\mathrm{m}^{-3}\right)\end{array}$ & $\begin{array}{l}\operatorname{LC}(\$ \\
\left.\mathrm{ha}^{-1}\right)\end{array}$ & $\begin{array}{l}\mathrm{FC}(\$ \\
\left.\mathrm{ha}^{-1}\right)\end{array}$ & $\begin{array}{l}\mathrm{MC}(\$ \\
\left.\mathrm{ha}^{-1}\right)\end{array}$ & $\begin{array}{l}\text { IC (\$ } \\
\left.\mathrm{ha}^{-1}\right)\end{array}$ & $\begin{array}{l}\text { TR1 (\$ } \\
\left.\mathrm{ha}^{-1}\right)\end{array}$ & $\begin{array}{l}\text { TR2 }(\$ \\
\left.\text { ha }^{-1}\right)\end{array}$ & $\begin{array}{l}\text { TC (\$ } \\
\left.\mathrm{ha}^{-1}\right)\end{array}$ & $\begin{array}{l}\text { TR }(\$ \\
\left.\mathrm{ha}^{-1}\right)\end{array}$ \\
\hline MP & 380.6 & $7,994.4$ & 0.58 & 999.3 & 0.58 & 299.8 & 488.8 & 270.3 & 159.5 & 562.52 & 402.46 & $1,218.4$ & 964.98 \\
\hline $\mathrm{TP}$ & 937.2 & $14,995.4$ & 1.94 & $1,874.4$ & 1.94 & 562.3 & NA & 220.8 & 135.5 & 687.58 & 351.27 & 918.6 & $1,038.85$ \\
\hline WC & 238.3 & $31,450.1$ & 9.54 & $3,931.3$ & 9.56 & $1,179.4$ & NA & 187.9 & 75.0 & 475.20 & 250.02 & $1,442.3$ & 725.22 \\
\hline GR & $1,191.2$ & $23,823.6$ & 1.03 & $2,978.0$ & 1.03 & 893.4 & NA & 170.2 & 200.0 & $1,230.12$ & 925.02 & $1,263.6$ & $2,155.14$ \\
\hline $\mathrm{RM}$ & NA & NA & NA & NA & NA & NA & NA & NA & NA & 281.88 & 189.00 & NA & 470.88 \\
\hline Significance & & $* *$ & & & & & & & & $* * *$ & $* * *$ & & \\
\hline $\mathrm{CV}(\%)$ & & 67.5 & & & & & & & & 55.2 & 69.1 & & \\
\hline
\end{tabular}

$I T$ irrigation technology, $M P$ motorized pump, $T P$ treadle pump, $W C$ water can, $G R$ gravity irrigation, $R M$ non-irrigated treatment using residual moisture, Sign. statistical significance: $* *$ and $* * *$ refer to significance at $p<0.01$ and $p<0.001$, respectively, $L E$ labour efficiency $\left(L H \mathrm{~m}^{-3}\right.$ ), $L C$ labour cost, calculated based on the measured hours per irrigation for each technology from Table 2 that allowed the estimations of LH ha ${ }^{-1}$ season $^{-1}, \mathrm{LD} \mathrm{ha}^{-1}, F C$ fuel cost, $M C$ maintenance cost, IC investment cost, $L D$ labourday, $L H$ labourhour, $T C$ total cost $\left(\left(\$ \mathrm{ha}^{-1}\right), T R 1\right.$ total revenue for BCMV-B2 $\left(\$ \mathrm{ha}^{-1}\right)$, TR2 total revenue for IZ-301-1 $\left(\$ \mathrm{ha}^{-1}\right), T R$ total revenue for the two bean lines $\left(\$ \mathrm{ha}^{-1}\right)$, labour cost $=\$ 0.30$ per labourday (MK33, using the exchange rate of MK110 $=\$ 1.00$, MK is Malawi Kwacha, the local currency), 1 labourday $=8$ working hours, price of bean grain $=\$ 0.54 \mathrm{~kg}^{-1}$ (An equivalent of $\mathrm{MK} 60 \mathrm{~kg}^{-1}$ ). Investment costs were depreciated using a sum of digits method assuming lifespans of 10, 5 and 2 years for MP and GR, TP and WC, respectively, as described in Johnston (1982). The maintenance costs for each irrigation technology were estimated from the work done in repairing or replacing some parts of the technology in question by using the cost of spare parts or any charges related to the repairs for each plot and subsequently converted to per ha. The investment cost for GR was estimated according to Kay (2001), assuming a lifespan of 10 years, NA not applicable 
approximately $\$ 490 \mathrm{ha}^{-1}$ pointing to the need for such poor farmers to receive fuel subsidies to offset operational and maintenance costs. Maintenance costs were highest with MP and lowest with GR. All the farmers involved in the study live on $<\$ 2$ day $^{-1}$. Thus, such high operational costs on MPs are well beyond their financial means as shown in the study. Considering the revenues realized at the end of the growing season, use of the WC and MP is not economical for such small-scale farmers owing to exorbitant labour and fuel costs, respectively.

\section{Conclusions and recommendations}

Grain yields differed significantly $(p<0.001)$ across irrigation technologies. Gravity-fed surface irrigation (GR) produced the highest mean yield, while farmers using RM realized lowest yield. GR, TP, MP and WC increase yields by 34-395 \% over use of RM. However, GR, TP and MP increase yields by over 33-239\% compared with WC. Despite high WUE obtained in using water can, the high labour costs ha ${ }^{-1}$, low yield and low revenue negate the use of the buckets in favour of TP, MP and GR. Considering labour efficiency, the study found that technologies that used $<2.00 \mathrm{LH} \mathrm{m}^{-3}$ were appropriate for such smallscale irrigation systems. The aggregated bean production labour cost and labourday thresholds were $\$ 893 \mathrm{ha}^{-1}$ and 2,978 $\mathrm{LD} \mathrm{ha}^{-1}$, respectively. In all irrigation scenarios, the dwarf bean BCMV-B2 produced WUPs approximately two times higher than those obtained in the climber line IZ3011. Though we did not quantify irrigation losses in the study, use of plastic lining on the main irrigation canals (for TP, MP and GR) or use of PVC pipes from the water source (in case of GR) would help in reducing deep percolation losses. Overall, the study finds that irrigated bean production appears to be an important strategy for increasing bean yield in the dry season in Malawi. However, poor smallscale farmers such as those in Chingale ADP (particularly those using MPs) need support systems through fuel subsidies in order to offset operational costs.

Basing on the findings in the study, we recommend further research on several bean lines in different agroecologies of Malawi using technologies that showed high yields, low labour efficiency and high water use productivity, for example, TP, MP and GR. Such an investigation could be done on fairly larger parcels of land to better assess the performance of technologies such as MP and GR that can irrigate $>0.4$ ha for two or more seasons to develop novel recommendations for small-scale irrigation management in Malawi. An irrigation supply in the range of 7,000-10,000 $\mathrm{m}^{3} \mathrm{ha}^{-1}$ per season for the TP, MP and GR would be adequate, taking into account deep percolation, conveyance and evaporation losses. Assuming 20 irrigations per season, $400-600 \mathrm{~m}^{3}$ per irrigation would be adequate, supplying 40-60 mm every 5-7 days. However, the surface water application for GR should be modified to furrow or corrugation, other than flooding as was the case in the study, to minimize deep percolation and other conveyance losses. With over $30 \%$ of the country covered by water, small-scale irrigation interventions would contribute significantly to increased crop and food production.

Acknowledgments The authors hereby acknowledge with thanks the financial support from United States Agency for International Development through the Bean/Cowpea Collaborative Research Support Program at Michigan State University. The cooperation from staff and farmers under World Vision Malawi in Chingale Area Development Program in Zomba district of southern Malawi during execution of the study is also gratefully acknowledged. This publication is a product of the research work done by the corresponding author for his Master of Science thesis in Agronomy at the University of Malawi.

\section{References}

Allen RG, Pereira LS, Raes D, Smith M (1998) Crop evapotranspiration-guidelines for computing crop water requirementsFAO irrigation and drainage paper 56. Rome. http://www.fao. org/docrep/X0490E/x0490e00.htm\#Contents. Accessed 2004

Chidanti-Malunga J, Weatherhead K (2009) Why is the treadle pump regarded as an appropriate technology amongst many small scale irrigation farmers in Malawi. J Appl Sci Res 5(3):323-328

Chimpeni M (2004) Smallscale irrigation-actionaid Malawi experience. In: Mangisoni JH (ed) Proceedings of stakeholders' experience and lesson sharing workshop on small scale irrigation and market development held at Malawi Institute of Management (MIM), Lilongwe, 27th-29th January, 2004, pp 38-45

Chisenga JC (2004) Availability and need for alternative microirrigation technologies and potential for expansion of support services. In: Mangisoni JH (ed) Proceedings of stakeholders' experience and lesson sharing workshop on small scale irrigation and market development held at Malawi Institute of Management (MIM), Lilongwe, 27th-29th January, 2004, pp 46-55

de Fraiture C, Wichelns D (2010) Satisfying future water demands for agriculture. Agric Water Manag 97:502-511

de Fraiture C, Molden D, Wichelns D (2010) Investing in water for food, ecosystems, and livelihoods: an overview of the comprehensive assessment of water management in agriculture. Agric Water Manag 97:495-501

Edje OT, Mughogho LK, Rao YP, Msuku WAB (1981) Bean production in Malawi. In Potentials for field beans in Eastern Africa. Proceedings of a regional workshop held in Lilongwe, Malawi 9-14 March, 1980

Fandika IR, Kadyampakeni D, Bottomani C, Kakhiwa H (2007) Comparative response of varied irrigated maize to organic and inorganic fertilizer application. Phys Chem Earth Parts A/B/C, 32(15-18):1107-1116

Fandika IR, Kadyampakeni D, Zingore S (2012) Performance of bucket drip irrigation by treadle pump on tomato and maize/bean production in Malawi. Irrig Sci 30:57-68

FAO (1996) Socio-economic and production system study of Wetland use. Main text and working papers 1 and 2

Ferguson AE, Mulwafu WO (2004) Irrigation reform on Malawi's Domasi and Likangala smallholder irrigation schemes: exploring 
land-water intersections. Final research report to BASIS CRSP, October 2004, Madison, WI

Fernández MD, González AM, Carreño J, Pérez C, Bonachela S (2007) Analysis of on farm irrigation performance in Mediterranean greenhouse. Agric Water Manag 89:251-260

Hansen VE, Israelsen OW, Strigham GE (1980) Irrigation principles and practices, 4th edn. Wiley, New York

Howell TA (2001) Enhancing water use efficiency in irrigated agriculture. Agron J 93(2):281-289

Johnston DT (1982) The business of farming: a guide to farm business management in the tropics. The Macmillan Press Ltd, London and Basingstoke

Kabutha C, Blank H, van Koppen B (2000) Drip irrigation kits for small-holder farmers in Kenya: experience and way forward. In: 6th international microirrigation congress, South Africa. 22-27 Oct 2000

Kadyampakeni D, Mangisoni JH, Singa DD, Mloza-Banda HR, Ferguson A, Snapp S, Mwendo-Phiri E (2008) Economic evaluation of irrigation and water management practices in Chingale Area Development Program, Zomba, Malawi. In: Nhira C, Mapiki A, Rankhumise P (eds) Land and water management in Southern Africa: towards sustainable agriculture. Pretoria, South Africa, pp 537-551

Kambewa D (2004) Patterns of access and use in wetlands: Lake Chilwa Basin. Research report to BASIS CRSP, October 2004, Madison, WI

Kay, M (2001) Smallholder irrigation technology: Prospects for subsaharan Africa. International programme for technology and research in irrigation and drainage, Food and Agriculture Organization of the United Nations, Rome, 2001, 42 pp

Kintomo AA, Ogunkeyede OO, Ogungbaigbe LO (1997) Peri-urban dry season vegetable production in Ibadan, Nigeria. National Horticultural Research Institute, Ibadan, Nigeria

Makwiza C (2008) Assessing and improving smallholder irrigation water management performance in Mulanje, southern Malawi. MSc thesis, Bunda College of Agriculture, University of Malawi, Lilongwe, Malawi

Malawi Government (2000) Feasibility study for irrigation of small farms in the region of Lake Littoral Project. Project report, vol 1

Mangisoni JH (1999) Land degradation, profitability and diffusion of erosion control technologies in Malawi, $\mathrm{PhD}$ thesis, University of Minnesota, USA

Mangisoni JH (2008) Impact of treadle pump irrigation technology on smallholder poverty and food security in Malawi: a case study of Blantyre and Mchinji districts. Int J Agric Sustain 6:248-266

Maweru SCY (2004) Current initiatives on microirrigation and smallholder markets in Malawi. In: Mangisoni, JH (ed)
Proceedings of stakeholders' experience and lesson sharing workshop on small scale irrigation and market development held at Malawi Institute of Management (MIM), Lilongwe, 27th-29th January, 2004, pp 19-24

Molden D, Murray-Rust H, Sakthivadivel R, Makin I (2003) A waterproductivity framework for understanding and action. In: Kijne JW, Barker R, Molden D (eds) Water productivity in agriculture: limits and opportunities for improvement. CAB International, Wallingford, pp 1-18

Mulwafu WO, Nkhoma BG (2002) The use and management of water in the Likangala Irrigation Scheme Complex in Southern Malawi. Phys Chem Earth 27:839-844

Mulwafu W, Chipeta C, Chavula G, Ferguson A, Nkhoma BG, Chilima G (2003) Water demand management in Malawi: problems and prospects for its promotion. Phys Chem Earth 28:787-796

Mwale VM, Bokosi JM, Masangano CM, Kwapata MB, Kabambe VH, Miles C (2008) Yield performance of dwarf bean (Phaseolus vulgaris L.) lines under Researcher Designed Farmer Managed (RDFM) system in three bean agro-ecological zones of Malawi. Afr J Biotechnol 7(16):2847-2853

Mwale VM, Bokosi JM, Masangano CM, Kwapata MB, Kabambe VH, Miles C (2009) Performance of climber common bean (Phaseolus vulgaris L.) lines under Researcher Designed Farmer Managed (RDFM) system in three bean agro-ecological zones of Malawi. Afr J Biotechnol 8(11):2460-2468

Mwendera EJ (2003) The use of wetlands for small-scale agricultural production in Swaziland. Int J Ecol Environ Sci 29(1):15-28

Nkhoma BG, Mulwafu WO (2004) The experience of irrigation management transfer in two irrigation schemes in Malawi, 1960s-2002. Phys Chem Earth 29:1327-1333

Pereira LS, Oweis T, Zairi A (2002) Irrigation management under water scarcity. Agric Water Manag 57(3):175-206

Peters PE (2004) Informal irrigation in Lake Chilwa Basin: Streambank and Wetland Gardens. Research report to BASIS CRSP, October 2004, Madison

Sinclair TR, Tanner CB, Bennet JM (1984) Water use efficiency in crop production. Bioscience 34:34-40

Tefera T (2006) Yield of common bean cultivars under semi-arid conditions in eastern Ethiopia. Trop Sci 46(3):155-159

Tindamanyire $\mathrm{T}$ (2003) Wetlands, water resources and agricultural productivity: an important synergy for biodiversity conservation. Int J Ecol Environ Sci 29(1):39-46

Wiyo KA, Lunduka RW, Nalivata PC (2002) Malawi treadle pump impact assessment study. Department of Irrigation, Ministry of Agriculture and Irrigation, Lilongwe 